\title{
ЕТИЧНІ ВИМІРИ ДІЯЛЬНОСТІ ПСИХОЛОГА В ПРАКТИЦІ ПСИХОЛОГІЧНОГО КОНСУЛЬТУВАННЯ
}

УДК: 159.923

\section{Яблонсъка Тетяна Миколаӥвна \\ Доктор психологічних наук, старший науковий співробітник, асистент кафедри психології розви- тку Київського Національного Університету імені Тараса Шевченка, м. Київ (Украӥна)}

\section{Булатевич Наталія Миколаӥвна}

Кандидат психологічних наук, дочент кафедри психології розвитку Київського Національного Університету імені Тараса Шевченка, м. Київ (Україна)

\begin{abstract}
Анотація. Стаття присвячена осмисленню проблеми етичних вимірів діяльності сучасного психолога. Проаналізовано зміст фундаментальних етичних норм, якими регламентується діяльність психологів в США, країнах Європи та в Україні. Окреслено низку дискусійних аспектів у сфері професійної етики психолога та наведено етичні дилеми, з яким зіштовхується професіонал в процесі психологічної практики. Здійснено емпіричне вивчення уявлень психологів про етичні засади психологічного консультування, а також уявлень клієнтів про етичні аспекти цฺього процесу. В результаті порівняння виявлено значущі розбіжності в уявленнях психологів та клієнтів. Зроблено висновок, щуо дані розбіжності свідчать про значущість для психолога та клієнта різних, проте взаємопов'язаних сторін консультативного процесу, щуо в сукупності є умовою ефективної взаємодії психолога та клієнта.
\end{abstract}

Ключові слова: професійна етика психолога, етичні изіності, етичні дилеми, психологічне консультування.

Постановка проблеми. Практична психологічна допомога є сьогодні актуальним і затребуваним у суспільстві напрямком професійної діяльності психолога. Суспільство дедалі більше усвідомлює важливість психологічної допомоги і супроводу людини в різ- них сферах іiі життєдіяльності: в начальновиховному процесі, в професійній діяльності, у процесі розв'язання особистісних та сімейних проблем, подолання складних життєвих обставин.

Значні суспільні зміни останніх років в 
Україні призвели до зростання числа людей, які потребують фахової психологічної допомоги. 3 іншого боку, в Україні набула поширення практика організації як психологами, так і представниками галузей знань, споріднених з психологією, численних семінарів, шкіл, інтенсивів з проблем практичної психології, де трапляються випадки порушення правил етики психолога [12]. Це ставить складні завдання перед психологами і вимагає від них вдосконалення професійних вмінь i, безперечно, дотримання високих професійних стандартів у роботі, передусім етичних. Саме професійні стандарти, професійна етика - це те, що забезпечує надання якісних психологічних послуг, а також захищеність інтересів як самого психолога, так і його клієнтів.

Аналіз останніх досліджень і публікацій. Під професійною етикою найчастіше розуміють систему моральних норм, цінностей, принципів поведінки, що слугує внутрішнім регулятором поведінки і взаємин у співтоваристві професіоналів [11]. Етичні норми в роботі психолога базуються на загальнолюдських моральних принципах: повазі особистості, iіi прав та свобод, доброзичливості, прагненні працювати на благо клієнта. Етичні принципи та правила роботи психолога формують умови, за яких зберігається і зростає його професіоналізм, гуманність його дій, реальна користь від його зусиль $[3 ; 7 ; 10]$.

Окрім загальних етичних засад, вироблені етичні норми, які є специфічними саме для професії психолога. Важливе місце серед них належить принципу конфіденційності та збереженню таємниці клієнта. Іншою специфічною етичною нормою є уникання фізичного контакту 3 клієнтами (окрім контакту, передбаченого експериментами чи техніками в процесі надання консультативної допомоги), а також соціальних контактів 3 ними, ділових та інших стосунків 3 клієнтами, окрім клієнт-терапевтичних [3].

Етичний кодекс EFPРА (Свропейської Федерації Професійних Психологічних Асоціацій), членом якої у 2017 році стала й Україна, включає низку положень, що регламентують професійну діяльність психолога, які об'єднані у 4 загальні принципи:

Повага прав та гідності клієнта - це, насамперед, усвідомлення й повага до знань і внутрішнього світу клієнта, уникання практик, які можуть вести до дискримінації; конфіденційність; базування роботи на інформованій згоді клієнта.

Компетентність передбачає усвідомлення психологом меж своєї компетентності, виходячи з освіти і досвіду, розуміння обмежень процедур та висновків для кожного конкретного випадку; професійний розвиток, відмову від практики, якщо особисті проблеми можуть негативно на неї вплинути.

Відповідальність означає відповідальність психолога за якість і наслідки впливу, дотримання високих стандартів; уникання зловживання психологічними знаннями і техніками; відповідальність перед клієнтом за 
вирішення етичних дилем, а також після завершення професійних стосунків.

Чесність та сумлінність передбачає чесність та коректність у стосунках з клієнтом та у професійному середовищі, точність у поданні інформації та гіпотез, професійних висновків; у фінансових питаннях консультування, уникання подвійних стосунків 3 клієнтом [16].

Етичні принципи, відображені в кодексі професійної етики Американської психологічної асоиіаціï, ухваленому (АПА) в 1981 році, перегукуються із названими положеннями. Серед них найважливішими є компетентність, цілісність (чесність, справедливість і повага до інших), професіоналізм і наукова відповідальність; повага до прав і гідності людей; турбота про благополуччя людей; соціальна відповідальність [15].

Питання етичного забезпечення дослідної та практичної діяльності психолога знайшли свій розвиток у Всезагальній декларації, яка була ухвалена Асамблеєю Міжнародного союзу психологічних наук в Берліні у 2008 році. Ця декларація формулює основні етичні принципи діяльноситі психологів, до яких відносяться: повага гідності людей i народів, компетентність, цілісність (основана на чесності, відкритих і точних комунікаціях психолога), професійні й наукові зобов'язання перед суспільством [17].

Отже, порівняння засадових документів основних авторитетних міжнародних про- фесійних об'єднань психологів дає можливість стверджувати, що етичні принципи діяльності психолога є достатньо послідовними i узгодженими у візії цих організацій.

В Украӥні проблема етичних стандартів професійної діяльності психолога розробляється як науково-освітніми інституціями, так і професійними об'єднаннями психологів. Визначною датою для української психології став 1991 рік, коли на I з'їзді товариства психологів України було прийнято етичний кодекс, який формулює основні етичні положення стосовно професійної діяльності психолога. Цей кодекс складається з семи частин, які розкривають основні етичні виміри роботи психолога: відповідальність, компетентність, захист інтересів клієнта, конфіденційність, етичні правила психологічних досліджень, кваліфікована пропаганда психології, професійна кооперація [8]. Впродовж останніх десятиліть в Україні створено численні психологічні асоціації, які провадять активну діяльність щодо інтеграції професійної спільноти, налагодження зв'язків із міжнародними організаціями, уточнення етичних принципів роботи психолога, вдосконалення професійних стандартів. Серед них слід відзначити Українську психологічну асоціацію, Українську асоціацію психології освіти та розвитку, Національну Психологічну Асоціацію (НПА). Остання була створена в 2017 році та є представником від України в ЕFРРА.

Проблема етичних принципів діяльносБулатевич Н. М. 
ті психолога, ціннісних основ його діяльності активно розробляються вітчизняними і зарубіжними дослідниками [2, 3, 4, 5, 7, 14]. Науковці відзначають, що професійна діяльність психолога - це робота з внутрішнім світом людини, з людською особистістю, що вимагає дотримання особливих принципів і правил етики. Ця «практична» етика консультанта спирається на узагальнене уявлення про психічну реальність, «карту душі» клієнта (тобто на психологічну теорію, якою керується спеціаліст), а також на парадигму життя психолога, емоційно-ціннісне ставлення до нього. Все це $\epsilon$ тією основою, на якій будується психологічний вплив на людину, визначає його вектор i глибину [1]

На думку дослідників [3, 9, 11], найбільш важливими етичними принципами діяльності психолога є: принщии професійної компетентності (психолог має знати свої права і обов'язки, професійні можливості і діяти лише в межах рівня професійної підготовленості); принщии ненанесення шкоди людині (діяльність психолога не повинна завдавати шкоди здоров'ю та інтересам людини); принu̧ип об'єктивності (психологу необхідно займати об'єктивну позицію, шляхом застосування стандартизованих, надійних, валідних, адаптованих методик та методів обробки та інтерпретації даних); принщии поваги клієнта (психолог повинен поважати гідність клієнта i проявляти чесність у спілкуванні з ним); дотримання професійної конфідениійності.
Зрозуміло, що задекларовані етичні принципи є лише загальними рекомендаціями щодо психологічної практики. Жоден етичний кодекс не може встановити, що є правильним в конкретній проблемній ситуації, але він є хорошим підгрунтям для прийняття таких рішень i виконує важливі функції, оскільки інформує як консультантів, так і їх клієнтів, а також широку громадськість щодо тих функцій та зобов'язань, які бере на себе психолог; є основою відповідальної практики, а також захисту клієнтів від неетичних дій консультанта; є базою рефлексії та вдосконалення психолога [14].

У сучасній психологічній практиці залишаються дискусійними багато етичних проблем діяльності психолога. Так, надмірне регулювання цієї діяльності призводить до формалізованих рішень психологів. Наприклад, у країнах, де зловживання в процесі надання психологічної допомоги караються юридично, психологи, щоб уникнути судових позовів, часто діють за принципом дотримання мінімуму вимог. Зрозуміло, що така орієнтація у діяльності психолога замість пошуку найкращого рішення для конкретного клієнта в конкретному випадку істотно впливає на ефективність психологічної допомоги. Тож сучасна професійна етика психолога, по суті, диференцієються на «обов'язкову етику» (mandatory ethics), тобто мінімум етичних правил та настанов, яких має дотримуватись психолог, та «бажану етику» (aspirational ehtic) - той piвень дотримання етичних настанов, коли пси- 
холог максимально діє в інтересах клієнта [14].

$€$ й інші аспекти діяльності психолога, пов'язані з етичними проблемами:

некоректне застосування психодіагностики у консультуванні (психотерапії) може мати такий негативний наслідок як віднесення клієнта до певної діагностичної категорії, а відповідно, його стигматизацію;

формалізований, технологічний підхід, що вимагає застосування коротких і стандартизованих інтервенцій. Такий підхід $є$ розвиненим у США та європейських країнах, насамперед через зацікавленість страхових компаній в обмеженні видів терапії, ефективної при конкретних розладах. Тут виникає низка етичних питань: чи не ставить страхова компанія бажання заощадження коштів вище потреб клієнтів? Чи достатньо надійними і валідними є рекомендовані техніки, зокрема у випадках, коли клієнти мають екзистенційні проблеми, які не вписуються в класифікації психічних розладів?

недостатньо визначене ставлення професійної спільноти до подвійних стосунків у консультуванні (поєднання ролей викладача $\mathrm{i}$ терапевта, супервізора і терапевта, консультування друзів, найманих працівників, родичів, спільний з клієнтом бізнес тощо), що є підгрунтям для виникнення етичних дилем у діяльності психолога. Однозначно неетичними визнаються сексуальні стосунки 3 клієнтами [14].

Вітчизняні дослідники, наголошуючи на винятковій особистісній значущості спілкування клієнта 3 психологом і можливих наслідках цього спілкування, підкреслюють, що від дотримання етичних принципів професійної діяльності залежить, яким буде втручання консультанта - таким, що розвиває, або таким, що руйнує особистість клієнта [2]. За їхніми даними, серед етичних дилем, з якими зіштовхується психолог у своїй роботі, найбільш типовими є:

спокуса влади як можливість зробити людей залежними для задоволення власних потреб;

проблема розподілу відповідальності психолога і клієнта;

проблема «професійної моди», що проявляється у гонитві за новими підходами і методиками, що не дозволяє опанувати їх досконало;

надмірне експериментування щодо методів надання допомоги і використання клієнтів як «матеріалу» для наукових досліджень, що відсуває на другий план власне допомогу клієнтові;

спокуса спекуляції на відсутності загальноприйнятих критеріїв оцінки ефективності консультаційної роботи, що створює ризик несумлінної роботи психолога.

До порушень професійної етики відносять також позицію заступництва й опіки з боку психолога, що може призвести до оцінної позиції по відношенню до клієнта, стереотипного стилю реагування на ситуації. Неприпустимими 
з боку психолога є демонстрація переваги, повчальність, директивність, снобізм, провокування конфронтаційних відносин [2].

Очевидно, багато питань професійної етики психолога не мають однозначних відповідей. Внутрішня активність і професіоналізм психолога мають проявлятися у тому, щоб самостійно знаходити відповіді на складні моральні питання. Водночас, за даними багатьох дослідників [11], етика у діяльності сучасних психологів часто має дифузний характер: психологи спираються на власну інтуїцію у вибоpi стратегій поведінки у складних і неоднозначних ситуаціях роботи. Нестача (або надлишок) законодавчого регулювання діяльності психолога, певна декларативність етичних принципів у поєднанні з нестачею професійного досвіду психолога та інтеграції професійної спільноти можуть призводити до помилок і порушень етичних норм.

Метою статті $є$ аналіз етичних вимірів професійної діяльності психолога через призму уявлень психологів та клієнтів про етичні аспекти діяльності психолога в процесі психологічного консультування.

Методика дослідження. 3 метою емпіричного вивчення уявлень психологів та клієнтів про етичні аспекти психологічного консультування використовувався авторський опитувальник на основі етичного кодексу психолога. Опитувальник поєднував твердження, які передбачали відкриті відповіді досліджуваних (за принципом незакінчених речень), та формулювання, які відображали основні вимоги етичного кодексу, із проханням оцінити ці позиції.

Так, для психологів були сформульовані наступні твердження для завершення «Етичними цінностями в моїй роботі $\epsilon . . . », ~ « В$ роботі з клієнтом я як психолог відповідальний за ...», «Неприпустимими та неетичними в роботі психолога вважаю...», «Зменшують довіру та дискредитують професію психолога такі дії психологів-консультантів...». Клієнтам пропонувалося завершити наступні речення: «Найціннішим в процесі консультування для мене було...», «Неприпустимим та неетичним в роботі психолога вважаю...», «Мені важко було би звернутися до психолога, який (яка)...», «Зменшують довіру до професії психолога такі дії психологів-консультантів...».

Також психологам та клієнтам був запропонований список аспектів роботи психолога із проханням оцінити їх важливість за 5бальною шкалою: «створення атмосфери довіри в процесі консультування», «емоційна підтримка», «життєвий досвід консультанта», «надання рекомендацій клієнту після закінчення консультації», «конфіденційність», «повага до клієнта як особистості незалежно від соціальної, релігійної, етнічної належності», «обговорення 3 клієнтом плану роботи та технік, які будуть застосовані», «професійний досвід консультанта», «чіткі і зрозумілі умови організації консультування і оплати роботи психолога», «роз'яснення психологом меж своєї 
відповідальності».

Категоріями контент-аналізу висловлювань психологів і клієнтів було обрано 4 основні принципи, відображені в етичному кодексі Європейської федерації професійних психологічних асоціацій (ЕFPРА): повага прав та гідності клієнта, відповідальність, компетентність, чесність і сумлінність [16]. Для обробки даних застосовувались контент-аналіз незакінчених речень, лінгвосмисловий аналіз частот висловлювань [6, 12], t-критерій Стьюдента, коефіцієнт кореляції Пірсона.

Виклад основного матеріалу та результатів дослідження. В результаті емпіричного дослідження було вивчено уявлення психологів та клієнтів про важливі етичні аспекти професійної діяльності психолога. Емпіричним дослідженням було охоплено 46 психологів віком від 22 до 59 років, середній вік 38,7 років, які мають стаж роботи від 1 до 34 років, середій стаж - 12,6 років, та 45 клієнтів віком від 24 до 46 років, середній вік 35,5 років.

В результаті аналізу даних опитування було виокремлено особливості уявлень психологів про етичні цінності та стандарти в їх професійній діяльності. Так, більшість опитаних психологів (78\%) вважають основою професійної діяльності конфіденційність і повагу до клієнта. Важливою підставою професійної діяльності психологи вважають розуміння меж своєї компетентності та професіоналізм (60\% опитаних). Третє місце за частотою згадувань посідають суб'єктивне благополуччя психолога та неприпустимість використання директив, порад і вказівок (30\% опитаних). 26\% опитаних важливими в роботі вважають опрацьованість психологом особистих проблем та його суб'єктивне благополуччя, дотримання умов контракту, відповідальне ставлення до використовуваних технік. Менш значущими, але часто згадуваними є такі аспекти діяльності як організація умов консультування та безпека клієнта (21\% опитаних), створення умов для особистісного розвитку клієнта (21\%).

В результаті контент-аналізу висловлювань психологів виявлено, що до категорії повага прав та гідності клієнта відносяться 37,2\% всіх висловлювань, їх згадують 95,7\% опитаних психологів.

25,62\% усіх висловлювань віднесено до категорії компетентність. 78,3\% опитаних психологів зазначають важливість тих стандартів своєї діяльності, які стосуються компетентності.

До категорії відповідальність віднесено 7,43\% від всіх висловлювань психологів. Відповідальність психолога як етична цінність і стандарт професійної роботи підкреслюється у відповідях 47,8\% опитаних психологів.

Висловлювання, які відносяться до категорії «чесність та сумлінність у професійному середовищі», складають 23,14\% всіх висловлювань і наявні у відповідях $82,7 \%$ опитаних психологів.

Аналіз частотності висловлювань, віднесених до певних категорій, дозволяє говори- 
ти про своєрідний «рейтинг», який репрезентує цінності й етичні норми професійної діяльності в уявленнях психологів. Отже, найважливіше місце посідають стандарти, пов'язані 3 повагою до особистості клієнта, дещо нижчу вагу мають принципи та стандарти, що описуються категоріями компетентність, чесність і сумлінність у професійному середовищі, найменшу -відповідальність.

В процесі аналізу виявлено висловлювання, які важко віднести до певної категорії i які описують емоційну, «людську» сторону стосунків між психологом та клієнтом. Це такі поняття як: «байдужість», «довіра», «емоційний комфорт», «стабільний емоційний стан», «емоційна та розумова включеність», «відкритість», «прийняття», «віра в клієнта». Ці висловлювання складають 6,61\%, проте їх згадують 47,8\% психологів, що свідчить про значущість емоційних аспектів їх діяльності.

Виявлено, що уявлення клієнтів про етичні засади і важливі аспекти консультативного процесу мають інший фокус. Найбільш значущими аспектами для них $\epsilon$ розуміння психологом суті проблеми та емоційна підтримка й увага (66,5\% опитаних). На другому місці знаходяться повага з боку психолога та надання рекомендацій (43\% опитаних), прагнення психолога допомогти відзначили 32\% клієнтів, компетентність - 23\% клієнтів. Цікаво, що дотримання конфіденційності, як важлива етична складова консультативного процесу, згадується лише у відповідях 11\% клієнтів, на противагу даним, отриманим на вібірці психологів.

В результаті контент-аналізу відповідей клієнтів за виокремленими категоріями 20,03\% всіх висловлювань було віднесено до категорії повага прав та гідності особистос$m i$, вони зустрічаються у відповідях 53,3\% опитаних клієнтів.

До категорії компетентність віднесено 18,3\% висловлювань; важливою цю професійну характеристику психолога вважають $40 \%$ опитаних клієнтів.

Категорія відповідальність охоплює 3,33\% всіх висловлювань; на важливості аспектів, пов'язаних з відповідальністю психолога, наголошують 22,2\% клієнтів.

5\% всіх висловлювань клієнтів віднесено до категорії чесність та сумлінність (психолога) у професійному середовищі. Про важливість цієї категорії свідчать відповіді $13,3 \%$ опитаних.

Низка відповідей клієнтів, так само, як і відповіді психологів, описують емоційну сторону стосунків між психологом та клієнтом. Вони складають 46,67\% всіх одиниць контент-аналізу і наявні у відповідях 86,7\% опитаних клієнтів, що свідчить про їх високу значущість.

Крім цього, у відповідях клієнтів зустрічаються висловлювання, що стосуються важливості порад та рекомендацій психолога $\mathrm{i}$ складають 6,67\% від усіх висловлювань. Оскільки про це зазначили 26,7\% клієнтів, то, очеБулатевич Н. М. 
видно, такі рекомендації для частини опитаних клієнтів мають значну цінність.

Серед неетичних моментів діяльності психолога і дій, що зменшують довіру до нього, клієнти називають молодий вік психолога («не має своїх дітей», «не має досвіду», 32,3\%), подвійні стосунки і маніпулятивність $(23,2 \%)$.

Про важливість різних аспектів консультативного процесу, їх значущість в роботі психолога свідчить частота їх згадувань при продовженні незакінчених речень. Зафіксовано відмінності щодо частоти і розгорнутості відповідей психологів і клієнтів. Психологи надають більш розгорнуті відповіді, частіше згадують той чи інший етичний принцип. Натомість, відповіді клієнтів відрізнялися стриманістю та лаконічністю. Для порівняння уявлень психологів і клієнтів щодо основних ети- чних принципів і важливих аспектів консультативного процесу було застосовано $\mathrm{t}$ критерій Стьюдента. Значущі відмінності подано у таблиці 1.

Як видно 3 табл. 1, розбіжності щодо вираженості виокремлених етичних категорій в уявленнях психологів і клієнтів $є$ досить суттєвими. Особливо це стосується таких категорій, частота яких є значущо вищою в уявленнях психологів: повага прав та гідності особистості ( $\leq \leq 0,001)$, чесність та сумлінність y професійному середовищі $(p \leq 0,003)$, компетентність $(p \leq 0,01)$. Висловлювання, які віднесені до категорії емоизйні аспекти взаємоdiï, значущо частіше зустрічались серед клієнтів $(p \leq 0,028)$. Ці відмінності в уявленнях психологів і клієнтів, на перший погляд, свідчать про суперечність: адже психологи більше орієнтовані на певну «рамку» і правила взаємодії,

Таблиця 1.

Значущі відмінності між уявленнями психологів і кліснтів щодо основних етичних принципів і важливих аспектів консультативного процесу за t-критерієм Стьюдента

\begin{tabular}{|c|c|c|c|}
\hline \multirow[t]{2}{*}{$\begin{array}{c}\text { Етичні принициии і важливі аспекти консу- } \\
\text { льтативного процесу }\end{array}$} & \multicolumn{2}{|c|}{$\begin{array}{c}\text { Показник згадувань у відпові- } \\
\text { дях }\end{array}$} & \multirow[t]{2}{*}{$\begin{array}{l}\text { Значущзість різ- } \\
\text { ниці середніх }\end{array}$} \\
\hline & Психологи & Кліснти & \\
\hline повага прав та гідності особистості & 3.91 & 1.33 & 0.001 \\
\hline компетентність & 2.69 & 0.55 & 0.01 \\
\hline відповідальність & 0.78 & 0.13 & 0.02 \\
\hline чесність та сумлінність & 2.43 & 0.22 & 0.003 \\
\hline емоційні аспекти взаємодії & 0.69 & 1.55 & 0.028 \\
\hline життєвий досвід консультанта & 2.86 & 4.17 & 0.001 \\
\hline професійний досвід консультанта & 4.09 & 4.61 & 0.056 \\
\hline надання рекомендацій & 2.8 & 4 & 0.017 \\
\hline обговорення плану роботи і технік & 2.68 & 4.07 & 0.02 \\
\hline
\end{tabular}


а клієнти - власне на емоційну підтримку, прийняття, співчуття, а також рекомендації психолога. Але насправді ця, здавалося б, суперечність в уявленнях психологів і клієнтів віддзеркалює різні взаємопов'язані сторони консультативного процесу. При цьому етичні вимоги, попри те, що вони не є власне предметом роботи і часто навіть до кінця не усвідомлюються клієнтом, забезпечують безпеку, довіру, співробітництво - власне ті умови, що уможливлюють взаємодію психолога й клієнта і виступають основою ефективної психологічної допомоги.

Кореляційний аналіз виявив, що зі збільшенням стажу консультативної практики психологи надають більшого значення для роботи життєвому досвіду $(\mathrm{r}=0,483 * ; \mathrm{p} \leq 0.03)$. Також 3 віком психолога зростає значущість професійного досвіду (r=0,467*; $\mathrm{p} \leq 0.03)$. Отже, життєвий і професійний досвід розглядається психологами як один з основних чинників ефективності їх професійної діяльності.

Для клієнтів такої залежності не виявлено; натомість зафіксовано обернений кореляційний зв'язок $(\mathrm{r}=-0,593 * ; \mathrm{p} \leq 0,033)$ між віком клієнта і важливістю обговорення плану та технік роботи. Тобто чим молодший клієнт, тим важливішим для нього є обговорення процедурної сторони консультування.

Висновки. Отже, етичні принципи професійної діяльності психолога спрямовані на утвердження загальнолюдських гуманітарних і соціальних цінностей; основними серед них $€$ повага до особистості, захист людських прав, почуття відповідальності, чесність і щирість стосовно клієнта, професійна компетентність, твердість у досягненні мети втручання і впевненість у його науковій основі. Проведене дослідження показало, що етичний кодекс психолога є надійною основою для побудови ефективної психологічної практики, водночас він не розв'язує всіх іiї суперечностей, а подекуди вступає в протиріччя з формами іiї організації.

Емпірично виявлено, що уявлення психологів про етичні виміри діяльності є досить послідовними і узгодженими, кореспондуються $з$ положеннями етичного кодексу i - що важливо - зі змістом уявлень клієнтів. Водночас зафіксовано відмінності в уявленнях психологів і клієнтів щодо значущості етичних принципів (повага прав та гідності клієнта, відповідальність, компетентність, чесність) і емоційних аспектів взаємодії, рекомендацій психолога, що зумовлено різним фокусом уваги психологів і клієнтів у консультативному процесі: більшою зорієнтованістю психологів на певну «рамку» і правила взаємодії, а клієнтів - власне на емоційну підтримку, що віддзеркалює різні взаємопов'язані сторони консультативного процесу. При цьому етичні вимоги, не будучи власне предметом роботи 3 клієнтом, забезпечують безпеку, довіру, співробітництво - власне ті умови, що є основою ефективної психологічної допомоги клієнту.

Перспектива дослідження проблеми професійної етики психолога вбачається в ра- 
курсі вдосконалення професійної підготовки майбутніх фахівців-психологів, оскільки саме звернення до ціннісної та етичної проблематики в процесі навчання має значний потенціал для розвитку їх професіоналізму.

\section{Перелік використаних джерел:}

1. Абрамова Г. С. Практическая психология: учебник для студентов вузов / Г.С.Абрамова. - Изд 6-е., перераб. и доп. - М.: Академический Проект, 2001. - 480 с.

2. Бочелюк В. И., Зарицька В. В. Психологія: вступ до спеціальності: навч. посібник / В. И. Бочелюк, В. В.Зарицька. - К., 2007. - 288 с.

3. Бондаренко А. Ф. Психологическая помощь: теория и практика / А.Ф. Бондаренко, изд. 4-е, испр. и доп. - К. : Освіта України, 2007. - 332 с.

4. Булатевич Н. М. Організація діяльності психологічної служби: навч. посібник / Н.М.Булатевич. Суми. СумДПУ ім. А.С.Макаренка, 2015. - 445 с.

5.Воробьева Л.И. Психотерапия и этика // Консультативная психология и психотерапия. - 2009. - №1. - С.80 $-98$.

6. Глухов В. П. Основы психолингвистики / В.П.Глухов. - М.: АСТ: Астрел, 2008. - 352 с.

7. Горбунова В. В. Етичні та правові аспекти психологічних досліджень // Практична психологія та соціальна робота / В.В.Горбунова. - № 3. - 2005. - С. $18-23$.

8. Іванова О. В., Корсун С.І., Москалюк Л.М. Психологія: вступ до спеціальності: навч. посібник / О.В.Іванова, С.І.Корсун, Л.М.Москалюк. - К.: Центр учбової літератури, 2013. - 184 с.

9. Карандашев В. Н. Психологія: Введення в професію / В.Н.Карандашев. - М.: Смысл, 2000. - 288 с.

10. Krylov A. A., Yurev A.I. Praktikum po obschey i eksperimentalnoy psihologii / Pod red. Krylova A.A., Manicheva S.A., 2-e izd. - SPb., Moskva, Harkov, Minsk, 2000.
$-\mathrm{S} .545-552$.

11. Myagotin A. V. Professionalnaya etika: sovremennyie tsennosti i smyislyi // Tsennosti i smyislyi. - 2011. - №2. S.74-80.

12. Носенко Е. Л. Етичний кодекс психолога України у світлі Європейського Мета-кодексу етики психологів // Практична психологія та соціальна робота. - 1998. - № 5. - C.2-3.

13.Тарасова E. B., Черемухин А.Д. Представления психологов-консультантов об этических ценностях, профессиональной устойчивости и жизнеспособности в деятельности // Universum: Психология и образование: электрон. научн. журн. - 2017. - № 4(34). URL: http://7universum. com/ru/psy/archive/item/4615

14. Corey $G$. Theory and Practice of Counseling and Psychotherapy. Brooks Cole, 2016. - 490 p., 10 edition.

15. Ethical Principles of Psychologists and Code of Conduct (Including 2010 and 2016 Amendments), http:// www.apa.org/ethics/code/index.aspx (accessed on 24.04.2018).

16. Meta-Code of Ethics, http://ethics.efpa.eu/metaandmodel-code/meta-code/ (accessed on 24.01.2018).

17. Universal Declaration of Ethical Principles for Psychologists, http://www.iupsys.net/about/governance/ universal-declaration-of-ethical-principles-forpsychologists.html\#pream-ble (accessed on: 24.04.2018).

\section{References (Transliteration):}

1. Abramova G. S. Prakticheskaya psihologiya: uchebnik dlya studentov vuzov / G.S.Abramova. - Izd 6-e., pererab. i dop. - M.: Akademicheskiy Proekt, 2001. - 480 s.

2. Bochelyuk V. I., Zaritska V. V. Psihologiya: vstup do spetsialnosti: navch. posibnyk / V. I. Bochelyuk, V. V.Zaritska. - K., 2007. - 288 s.

3. Bondarenko A. F. Psychological help: theory and practice / A.F. Bondarenko, K.: Osvita Ukraini, 2007. - 332 s.

4. Bulatevich N. M. Organizatsiya diyalnosti psihologichnoyi sluzhby: navch. posibnyk / N.M.Bulatevich. Sumy. SumDPU im. 
A.S.Makarenka, 2015. - 445 s.

5. Vorobeva L. I. Psihoterapiya i etika // Konsultativnaya psihologiya i psihoterapiya. - 2009. - №1. - S. 80-98.

6. Gluhov V. P. Osnovyi psiholingvistiki / V.P.Gluhov. - M.: AST: Astrel, 2008. - 352 s.

7. Gorbunova $V$. $\quad V$. Etichni ta pravovi aspekti psihologichnyh doslidzhen // Praktichna psihologiya ta sotsialna robota / V.V.Gorbunova. - № 3. - 2005. - S. 18-23.

8. Ivanova O. V., Korsun S.I., Moskalyuk L.M. Psihologiya: vstup do spetsialnosti: navch. posibnik / O.V.Ivanova, S.I.Korsun, L.M.Moskalyuk. - K.: Tsentr uchbovoyi literatury, 2013. - $184 \mathrm{~s}$.

9. Karandashev V. N. Psihologiya: Vvedennya v profesiyu /

V.N.Karandashev. - M.:Smysl, 2000. - 288 s.

10. Krylov A. A., Yurev A.I. Praktikum po obschey i eksperimentalnoy psihologii / Pod red. Krylova A.A., Manicheva S.A., 2-e izd. - SPb., Moskva, Harkov, Minsk, 2000. $-\mathrm{S} .545-552$.

11. Myagotin A. V. Professionalnaya etika: sovremennyie tsennosti i smyislyi // Tsennosti i smyislyi. - 2011. - №2. S.74-80.

12. Nosenko E. L. Etichiy kodeks psyhologa Ukrayyni u svitli yevropeyskogo meta kodeksu etiki psihologiv // Praktichna psihologiya ta sotsialna robota. - 1998 - № 5. - S.23.

13. Tarasova E. V., Cheremuhin A.D. Predstavleniya psihologov-konsultantov ob eticheskih tsennostyah, professionalnoy ustoychivosti i zhiznesposobnosti v deyatelnosti // Universum: Psihologiya i obrazovanie: elektron. nauchn. zhurn. - 2017. - № 4(34). URL: http://7universum. $\mathrm{com} / \mathrm{ru} / \mathrm{psy} /$ archive/item/4615

14. Corey G. Theory and Practice of Counseling and Psychotherapy. Brooks Cole, 2016. - 490 p., 10 edition.

15. Ethical Principles of Psychologists and Code of Conduct (Including 2010 and 2016 Amendments), http:// www.apa.org/ethics/code/index.aspx (accessed on 24.04.2018).

16. Meta-Code of Ethics, http://ethics.efpa.eu/metaandmodel-code/meta-code/ (accessed on 24.04.2018).
17. Universal Declaration of Ethical Principles for Psychologists, http:/www.iupsys.net/about/governance/ universal-declaration-of-ethical-principles-forpsychologists.html\#pream-ble (accessed on: 24.01.2018).

\section{Yablonska Tetiana}

Doctor of Psychology, Taras Shevchenko National University of Kyiv, Kyiv (Ukraine)

\section{Bulatevych Natalia}

PhD in Psychology, Taras Shevchenko National University of Kyiv, Kyiv (Ukraine)

\section{ETHICAL DIMENSIONS OF THE PSYCHOLOGIST'S ACTIVITY IN THE PRACTICE OF PSYCHOLOGICAL COUNSELING}

\section{ABSTRACT}

The article is devoted to comprehension of a problem of ethical dimensions of psychologist's professional activity. The content of fundamental ethical norms, which regulates the activity of psychologists in the USA, Europe and Ukraine, is analyzed. A comparative analysis of the main categories and requirements of the ethical codes of authoritative international associations of psychologists is carried out. It is established that the ethical principles of psychologists' professional activity are aimed at the confirmation of universal humanitarian and social values; the main among them is respect for the person, protection of human rights, sense of responsibility, honesty and sincerity in relation to the client, professional competence. The conducted research showed that psychologist's ethical code is a sufficiently reliable basis for building an effective 
psychological practice, at the same time it does not resolve all its contradictions, and sometimes comes into collision with the forms of its organization. A number of discussion aspects in the field of ethical regulation of the psychologist's activities are outlined and ethical dilemmas encountered by a professional in the process of psychological practice are given.

An empirical study of psychologist's and client's representations of ethical aspects of psychological counseling was carried out using an author's questionnaire based on the psychologist's ethical code. The main principles reflected in the ethical code of the European Federation of Professional Psychological Associations were selected as a categories of content analysis of psychologist's and client's statements: respect for the client's rights and dignity, responsibility, competence, honesty and integrity. Content analysis of unfinished sentences, linguistic and semantic analysis of a statement frequency, Student's t-criterion, and Pearson correlation coefficient were used for the data processing.

An empirical study found out that psychologist's representation about ethical principles of the activity is fairly consistent and consequential, correspond to the thesis of the ethical code, as well as with the content of client's representations. At the same time, differences in the psychologist's and client's representations about the importance of ethical principles (respect for the client's rights and dignity, responsibility, competence, honesty and integrity) and emotional as- pects of interaction, psychologist's recommendations are pinpointed. This is determined by the different focus of psychologist's and client's attention during counseling: more psychologist's orientation on a certain "framework" and the rules of interaction, and client's - in fact, on emotional support, which reflects the various but interdepended parts of counseling. At the same time, ethical requirements, not being the subject of work with the client, provide security, trust, cooperation - the exactly conditions which are the basis of effective psychological assistance to the client.

Keywords: psychologist's professional ethics, ethical values, ethical dilemmas, psychological counseling.

\section{Яблонская Татьяна}

Доктор психологических наук, Киевский национальный университет имени Тараса Шевченко, г. Киев (Украина)

\section{Булатевич Наталья}

Кандидат психологических наук, Киевский национальный университет имени Тараса Шевченко, г. Киев (Украина)

\section{ЭТИЧЕСКИЕ ИЗМЕРЕНИЯ ДЕЯТЕЛЬНОСТИ ПСИХОЛОГА В ПРАКТИКЕ ПСИХОЛОГИЧЕСКОГО КОНСУЛЬТИРОВАНИЯ}

Аннотация. Статья посвящена осмыслению проблемы этических измерений профессиональной деятельности психолога. Проанализировано содержание фундаментальных 
этических норм, которыми регламентируется деятельность психологов в США, странах Европы и в Украине. Проведен сравнительный анализ основных категорий и требований этических кодексов авторитетных международных объединений психологов. Установлено, что этические принципы профессиональной деятельности психолога направлены на утверждение общечеловеческих гуманитарных и социальных ценностей; основными среди них выступают уважение к личности, защита прав человека, чувство ответственности, честность и искренности по отношению к клиенту, профессиональная компетентность. Проведенное исследование показало, что этический кодекс является достаточно надежной основой для построения эффективной психологической практики, в то же время он не решает всех ее противоречий, а иногда вступает в противоречие с формами ее организации. Очерчен ряд дискуссионных аспектов в сфере этического регулирования деятельности психолога и приведены этические дилеммы, с которыми сталкивается профессионал в процессе психологической практики.

Эмпирическое исследование представлений психологов и клиентов об этических аспектах психологического консультирования проводилось с использованием авторского опросника на основе этического кодекса психолога. Категориями контент-анализа высказываний психологов и клиентов были выбраны основные принципы, отраженные в этиче- ском кодексе Европейской федерации профессиональный психологических ассоциаций: уважение прав и достоинства клиента, ответственность, компетентность, честность и добросовестность. Для обработки данных применялся контент-анализ незаконченных предложений, лингвосмысловой анализ частоты высказываний, t-критерий Стьюдента, коэффициент корреляции Пирсона.

Эмпирическое исследование показало, что представления психологов об этических принципах деятельности являются достаточно последовательными и согласованными, корреспондируют с положениями этического кодекca, a также с содержанием представлений клиентов. В то же время зафиксированы отличия в представлениях психологов и клиєнтов относительно значимости этических принципов (уважение прав и достоинства клиента, ответственность, компетентность, честность и добросовестность) и эмоциональных аспектов взаимодействия, рекомендаций психолога, что обусловлено разным фокусом внимания психологов и клиентов в консультативном процессе: большей ориентированностью психологов на определенную «рамку» и правила взаимодействия, а клиентов - собственно на эмоциональную поддержку, что отображает разные взаимосвязанные стороны консультативного процесса. При этом этические требования, не будучи собственно предметом работы с клиентом, обеспечивают безопасность, доверие, сотрудничество - именно те условия, коБулатевич Н. М. 
торые являются основой эффективной психологической помощи клиенту.

Ключевые слова: профессиональная этика психолога, этические ценности, этические дилеммы, психологическое консультирование. 